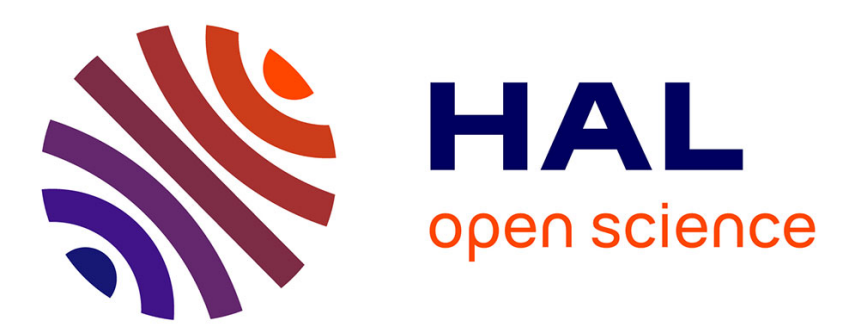

\title{
Finite solid angle correction factors and efficiencies for cadmium telluride detectors
}

\author{
A.K. Chaubey, H.V. Gupta
}

\section{To cite this version:}

A.K. Chaubey, H.V. Gupta. Finite solid angle correction factors and efficiencies for cadmium telluride detectors. Revue de Physique Appliquée, 1977, 12 (2), pp.313-319. 10.1051/rphysap:01977001202031300 . jpa-00244165

\section{HAL Id: jpa-00244165 https://hal.science/jpa-00244165}

Submitted on 1 Jan 1977

HAL is a multi-disciplinary open access archive for the deposit and dissemination of scientific research documents, whether they are published or not. The documents may come from teaching and research institutions in France or abroad, or from public or private research centers.
L'archive ouverte pluridisciplinaire HAL, est destinée au dépôt et à la diffusion de documents scientifiques de niveau recherche, publiés ou non, émanant des établissements d'enseignement et de recherche français ou étrangers, des laboratoires publics ou privés. 


\title{
FINITE SOLID ANGLE CORRECTION FACTORS AND EFFICIENCIES FOR CADMIUM TELLURIDE DETECTORS
}

\author{
A. K. CHAUBEY and H. V. GUPTA (*) \\ Department of Physics, Aligarh Muslim University Aligarh 202001, India
}

\begin{abstract}
Résumé. - On calcule les facteurs de correction d'angle solide et les efficacités de détection de compteurs $\mathrm{CdTe}$ de forme cylindrique droite pour des sources de rayonnements $\gamma$ ponctuelles d'énergies comprises entre $100 \mathrm{keV}$ et $10 \mathrm{MeV}$ placées le long de l'axe du cylindre. Différentes distances source-détecteur, allant de 1 à $10 \mathrm{~cm}$ ont été considérées ainsi que des diodes de différentes surfaces, comprises entre 0,12 et $2,5 \mathrm{~cm}^{2}$ et de différentes épaisseurs.
\end{abstract}

Abstract. - Finite solid angle correction factors and absolute detection efficiencies of the CdTe detectors of right circular cylindrical geometry for point sources placed on the axis of the detector, has been calculated for $\gamma$-ray energies from $100 \mathrm{keV}$ to $10 \mathrm{MeV}$, taking into account various source to detector distances, ranging from 1 to $10 \mathrm{~cm}$. CdTe detectors of several area between 0.12 and $2.5 \mathrm{~cm}^{2}$ of various thicknesses were considered.

1. Introduction. - During last few years utilisation of $\mathrm{Ge}(\mathrm{Li})$ and $\mathrm{Si}(\mathrm{Li})$ detectors has gained wide popularity in the field of gamma ray spectroscopy. The success of silicon and germanium has opened the ways for using other semiconductor materials as a detector. For last five years a new compound semiconductor Cadmium-Telluride, being a wider band gap and higher $Z$, has been under active development for this purpose at a number of laboratories [1-3] and recently good gamma ray energy resolution has been obtained. Moreover, CdTe detector can be operated in large temperature range $\left(+125^{\circ} \mathrm{C}\right.$ to $-150^{\circ} \mathrm{C}$ ) obviously, no need of cooling agent. With an increase in the availability of large volume CdTe crystals provided the trapping problems can be overcome, in the future the nuclear spectroscopist would prefer these detectors in the study of several problems such as gamma-gamma angular correlation experiments etc. due to its higher absorption crosssection for gamma rays.

Regarding the use of any CdTe detector for gamma ray spectrometry one would ideally like to have a detailed knowledge of the absolute detection efficiencies and finite solid angle corrections for the gammagamma angular correlation experiments. Several papers have been presented on the detection efficiency and on the finite solid angle correction factors for $\mathrm{Ge}(\mathrm{Li})$ detectors [4]. Nevertheless, none has yet appeared for CdTe detectors.

In the present paper we have calculated total detection efficiency and angular correlation attenuation factors of different sizes CdTe detectors in the gamma

(*) Present address : Department of Meteorology, Bombay Air Port, Bombay. ray energy range from $100 \mathrm{keV}$ to $10 \mathrm{MeV}$ taking into account various source to detector distances.

2. Calculation and results. - The detection efficiency of the detector is defined as the ratio of the number of counts to the number of gamma rays emitted by the source. For the crystal to source geometry shown in figure 1 the absolute detection

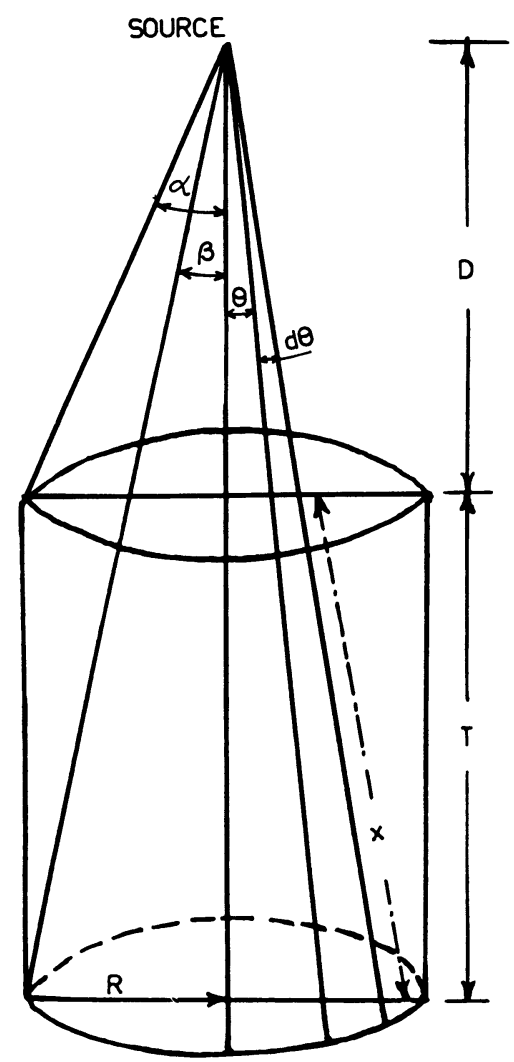

Fig. 1. - Geometry arrangement of the cylindrical detector with point source. 
efficiency $\varepsilon(E)$ for gamma ray of energy $E$ is defined by ;

$\varepsilon(E)=\int_{0}^{\alpha}[1-\exp \{-\mu(E) x(\theta)\}] \frac{2 \pi \sin \theta \mathrm{d} \theta}{4 \pi}$

where $\mu(E)$ is the total absorption cofficient for the gamma ray of energy $E$ in the crystal. $x(\theta)$ is the thickness of the detector as seen by the particular gamma ray incident at an angle $\theta$ with respect to the axis of the detector and $2 \pi \sin \theta \mathrm{d} \theta / 4 \pi$ is the probability that an emitted quantum lies within the solid angle between $\theta$ and $\theta+\mathrm{d} \theta$. From figure $1 x(\theta)$ can be obtained as follows :

$$
\begin{gathered}
x(\theta)=T \sec \theta ; \text { for } 0 \leqslant \theta \leqslant \tan ^{-1} \frac{R}{D+T}=\beta \\
x(\theta)=R \operatorname{cosec} \theta-D \sec \theta,
\end{gathered}
$$

for

$$
\beta \leqslant \theta \leqslant \tan ^{-1} \frac{R}{D}=\alpha .
$$

Now the efficiency can be obtained as

$$
\varepsilon(E)=\frac{1}{2}\left(I_{1}-I_{2}-I_{3}\right)
$$

where

$$
\begin{aligned}
& I_{1}=\int_{0}^{\alpha} \sin \theta \mathrm{d} \theta \\
& I_{2}=\int_{0}^{\beta} \exp [-\mu(E) x(\theta)] \sin \theta \mathrm{d} \theta \\
& I_{3}=\int_{\beta}^{\alpha} \exp [-\mu(E) x(\theta)] \sin \theta \mathrm{d} \theta .
\end{aligned}
$$

In the analysis of the angular correlation experiments, theoretically the probability $W(\theta)$ may be expressed in terms of Legendre polynomials $[5,6]$

$$
W(\theta)=1+A_{2} P_{2}(\cos \theta)+A_{4} P_{4}(\cos \theta)+\cdots
$$

where

$$
A_{i}=A_{i} \exp / Q_{i} \quad(i=2,4,6, \cdots)
$$

In practice, $i=2$ and 4 only are sufficient. According to Rose [5] $Q_{i}$ 's can be explained in terms of the detector efficiencies

$Q_{i}=\frac{J_{i}}{J_{0}}=\frac{\int_{0}^{\alpha} P_{i}[1-\exp \{-\mu(E) x(\theta)\}] \sin \theta \mathrm{d} \theta}{\int_{0}^{\alpha}[1-\exp \{-\mu(E) x(\theta)\}] \sin \theta \mathrm{d} \theta}$.

The integrals involved in equations (3) and (6) have been calculated using Simpson's method on the computer. Before doing the calculations we made certain assumptions, that the detector has the shape of a right circular cylinder and the source is a point source placed on the axis of the detector. We have also assumed that there was no absorber between the source and detector. If, however there is a window before the crystal a multiplying factor $\exp \left[-\mu_{\mathrm{A}}(E) x(\theta)\right]$ must be included in each integral, where $\mu_{\mathrm{A}}(E)$ is the absorption coefficient of gamma rays for that particular absorber. The $\mu(E)$ values from $100 \mathrm{keV}$ to $10 \mathrm{MeV}$ for CdTe absorbers were calculated from the tables [7]. The $\mu(E)$ and gamma ray energy $E$ for CdTe have been given in table $I$. Results for the $\varepsilon(E)^{\prime} \mathrm{s}$ in percentage for the ten different detectors are shown in figures 2 to 8 . It should be noted that the efficiency of CdTe detectors is very much higher than thot of $\mathrm{Ge}(\mathrm{Li})$. The results for the finite solid angular correction factors are presented in table II-XI.

\section{TABLE I}

\begin{tabular}{|c|c|c|c|}
\hline \multicolumn{2}{|c|}{$\begin{array}{l}\text { Energy } \\
(\mathrm{MeV})\end{array}$} & $J_{2} / J_{0}$ & $J_{4} / J_{0}$ \\
\hline Source & 0.1 & 0.9024 & 0.6993 \\
\hline distance & 0.2 & 0.9026 & 0.6997 \\
\hline $1.0 \mathrm{~cm}$ & 0.3 to 10.0 & 0.9026 & 0.6998 \\
\hline Source & 0.1 to 10.0 & 0.9876 & 0.9592 \\
\hline
\end{tabular}

Values of gamma ray attenuation coefficients

$\begin{array}{cccc}\begin{array}{c}\text { Energy } \\ (\mathrm{MeV})\end{array} & \begin{array}{c}\mu \\ \left(\mathrm{cm}^{-1}\right)\end{array} & \begin{array}{c}\text { Energy } \\ (\mathrm{MeV})\end{array} & \begin{array}{c}\mu \\ \left(\mathrm{cm}^{-1}\right)\end{array} \\ \overline{0.1} & 12.046 & \overline{1.0} & 0.4209 \\ 0.2 & 2.347 & 2.0 & 0.2994 \\ 0.3 & 1.179 & 4.0 & 0.2594 \\ 0.4 & 0.8376 & 6.0 & 0.2506 \\ 0.6 & 0.5883 & 8.0 & 0.2591 \\ 0.8 & 0.4855 & 10.0 & 0.2707\end{array}$

Finite solid angle correction factors.

\section{TABLE II}

AREA $0.125 \mathrm{~cm}^{2}$, radius $0.2 \mathrm{~cm}$, thickness $0.05 \mathrm{~cm}$

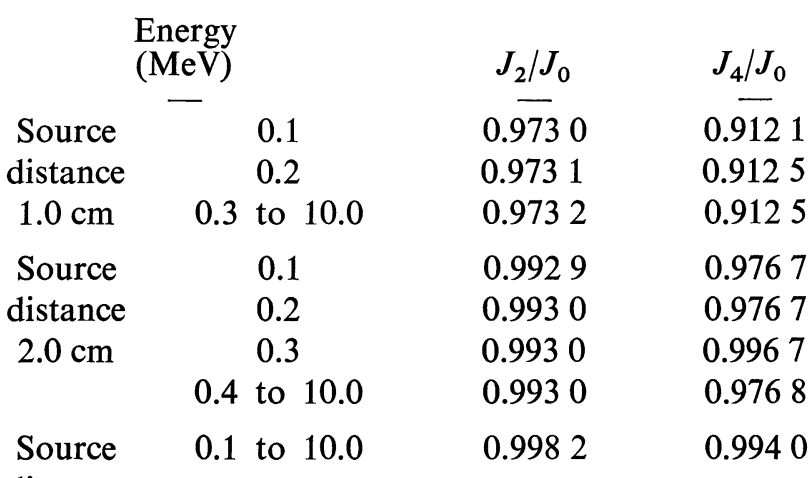

TABLE III

AREA $0.5 \mathrm{~cm}^{2}$, radius $0.3981 \mathrm{~cm}$, thickness $0.05 \mathrm{~cm}$

distance

$3.0 \mathrm{~cm}$

$\begin{array}{llll}\text { Source } & 0.1 \text { to } 10.0 & 0.9954 & 0.9850\end{array}$

distance

$5.0 \mathrm{~cm}$ 
TABLE IV

AREA $1 \mathrm{~cm}^{2}$, radius $0.5642 \mathrm{~cm}$, thickness $0.1 \mathrm{~cm}$

\begin{tabular}{|c|c|c|c|}
\hline \multicolumn{2}{|c|}{$\begin{array}{l}\text { Energy } \\
(\mathrm{MeV})\end{array}$} & $J_{2} / J_{0}$ & $J_{4} / J_{0}$ \\
\hline $\begin{array}{l}\text { Source } \\
\text { distance } \\
1.0 \mathrm{~cm}\end{array}$ & $\begin{aligned} & 0.1 \\
& 0.2 \\
& 0.3 \\
& 0.4 \\
0.6 & \text { to } 10.0\end{aligned}$ & $\begin{array}{l}0.8280 \\
0.8291 \\
0.8292 \\
0.8292 \\
0.8293\end{array}$ & $\begin{array}{l}0.5028 \\
0.5052 \\
0.5055 \\
0.5055 \\
0.5056\end{array}$ \\
\hline $\begin{array}{c}\text { Source } \\
\text { distance } \\
2.0 \mathrm{~cm}\end{array}$ & $\begin{array}{c}0.1 \\
0.2 \\
0.3 \text { to } 10.0\end{array}$ & $\begin{array}{l}0.9478 \\
0.9482 \\
0.9482\end{array}$ & $\begin{array}{l}0.8333 \\
0.8342 \\
0.8344\end{array}$ \\
\hline $\begin{array}{l}\text { Source } \\
\text { distance } \\
3.0 \mathrm{~cm}\end{array}$ & $\begin{array}{c}0.1 \\
0.2 \\
0.3 \\
0.4 \text { to } 10.0\end{array}$ & $\begin{array}{l}0.9757 \\
0.9758 \\
0.9758 \\
0.9759\end{array}$ & $\begin{array}{ll}0.920 & 7 \\
0.921 & 1 \\
0.921 & 1 \\
0.921 & 2\end{array}$ \\
\hline $\begin{array}{l}\text { Source } \\
\text { distance } \\
4.0 \mathrm{~cm}\end{array}$ & $\begin{array}{l}0.1 \\
0.2 \text { to } 10.0\end{array}$ & $\begin{array}{l}0.9861 \\
0.9861\end{array}$ & $\begin{array}{l}0.9542 \\
0.9544\end{array}$ \\
\hline $\begin{array}{c}\text { Source } \\
\text { distance } \\
6.0 \mathrm{~cm}\end{array}$ & $\begin{array}{c}0.1 \\
0.2 \text { to } 10.0\end{array}$ & $\begin{array}{l}0.9937 \\
0.9937\end{array}$ & $\begin{array}{l}0.9792 \\
0.9793\end{array}$ \\
\hline
\end{tabular}

TABLE V

AREA $1 \mathrm{~cm}^{2}$, radius $0.5642 \mathrm{~cm}$, thickness $0.3 \mathrm{~cm}$

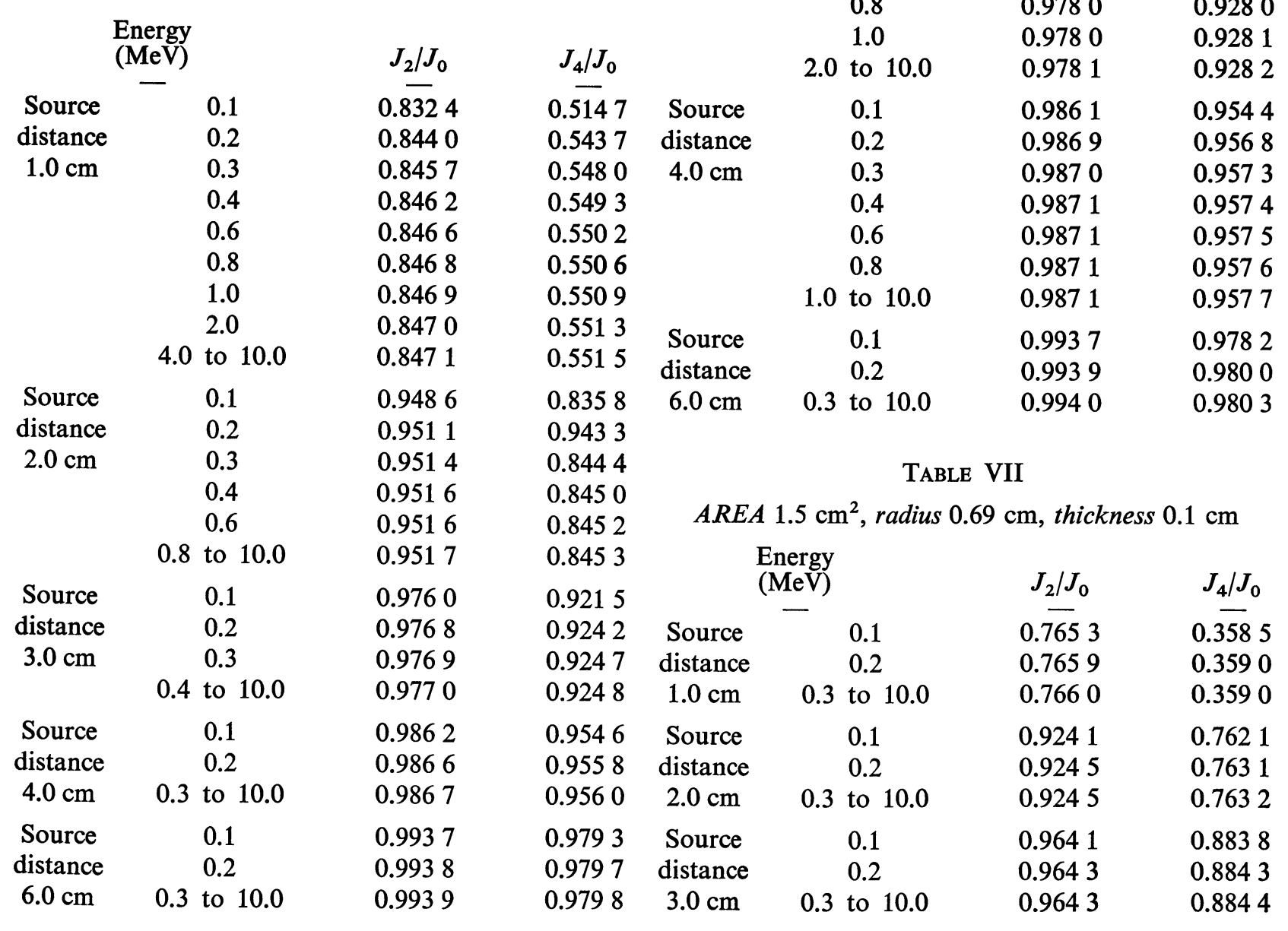

AREA $1.0 \mathrm{~cm}^{2}$, radius $0.5642 \mathrm{~cm}$, thickness $0.5 \mathrm{~cm}$

\begin{tabular}{|c|c|c|c|}
\hline & $\begin{array}{l}\text { aergy } \\
\text { (eV) }\end{array}$ & $J_{2} / J_{0}$ & $J_{4} / J_{0}$ \\
\hline Source & 0.1 & $0 . \overline{831} 9$ & $0 . \overline{513} 2$ \\
\hline distance & 0.2 & 0.8524 & 0.5659 \\
\hline $1.0 \mathrm{~cm}$ & 0.3 & 0.8565 & 0.5766 \\
\hline & 0.4 & 0.8577 & 0.5798 \\
\hline & 0.6 & 0.8586 & 0.5822 \\
\hline & 0.8 & 0.8590 & 0.5832 \\
\hline & 1.0 & 0.8593 & 0.5832 \\
\hline & 2.0 & 0.8597 & 0.5850 \\
\hline & 4.0 to 10.0 & 0.8599 & 0.5854 \\
\hline Source & 0.1 & 0.9484 & 0.8350 \\
\hline distance & 0.2 & 0.9529 & 0.8491 \\
\hline $2.0 \mathrm{~cm}$ & 0.3 & 0.9538 & 0.8519 \\
\hline & 0.4 & 0.9541 & 0.8527 \\
\hline & 0.6 & 0.9543 & 0.8533 \\
\hline & 0.8 & 0.9544 & 0.8536 \\
\hline & 1.0 & 0.9544 & 0.8537 \\
\hline & 2.0 & 0.9545 & 0.8540 \\
\hline & 4.0 to 10.0 & 0.9546 & 0.8541 \\
\hline Source & 0.1 & 0.9759 & 0.9212 \\
\hline distance & 0.2 & 0.9775 & 0.9264 \\
\hline $3.0 \mathrm{~cm}$ & 0.3 & 0.9778 & 0.9274 \\
\hline & 0.4 & 0.9779 & 0.9277 \\
\hline & 0.6 & 0.9780 & 0.9279 \\
\hline & 0.8 & 0.9780 & 0.9280 \\
\hline & 1.0 & 0.9780 & 0.9281 \\
\hline & 2.0 to 10.0 & 0.9781 & 0.9282 \\
\hline Source & 0.1 & 0.9861 & 0.9544 \\
\hline distance & 0.2 & 0.9869 & 0.9568 \\
\hline $4.0 \mathrm{~cm}$ & 0.3 & 0.9870 & 0.9573 \\
\hline & 0.4 & 0.9871 & 0.9574 \\
\hline & 0.6 & 0.9871 & 0.9575 \\
\hline & 0.8 & 0.9871 & 0.9576 \\
\hline & 1.0 to 10.0 & 0.9871 & 0.9577 \\
\hline Source & 0.1 & 0.9937 & 0.9782 \\
\hline distance & 0.2 & 0.9939 & 0.9800 \\
\hline $6.0 \mathrm{~cm}$ & 0.3 to 10.0 & 0.9940 & 0.9803 \\
\hline
\end{tabular}


TABLE VII (suite)

\begin{tabular}{|c|c|c|c|}
\hline $\begin{array}{c}\text { Source } \\
\text { distance } \\
4.0 \mathrm{~cm}\end{array}$ & $\begin{array}{l}0.1 \\
0.2 \text { to } 10.0\end{array}$ & $\begin{array}{l}0.9793 \\
0.9794\end{array}$ & $\begin{array}{l}0.9322 \\
0.9325\end{array}$ \\
\hline $\begin{array}{c}\text { Source } \\
\text { distance } \\
6.0 \mathrm{~cm}\end{array}$ & $\begin{array}{c}0.1 \\
0.2 \text { to } 10.0\end{array}$ & $\begin{array}{l}0.9906 \\
0.9906\end{array}$ & $\begin{array}{l}0.9690 \\
0.9691\end{array}$ \\
\hline \multicolumn{3}{|c|}{ TABLE VIII } & $2 \mathrm{~cm}$ \\
\hline & & $J_{2} / J_{0}$ & $J_{4} / J_{0}$ \\
\hline $\begin{array}{c}\text { Source } \\
\text { distance } \\
1.0 \mathrm{~cm}\end{array}$ & $\begin{array}{l}0.1 \\
0.2 \\
0.3 \\
0.4 \\
0.6 \\
0.8 \\
1.0 \text { to } 10.0\end{array}$ & $\begin{array}{l}0.7190 \\
0.7255 \\
0.7262 \\
0.7264 \\
0.7266 \\
0.7266 \\
0.7267\end{array}$ & $\begin{array}{l}0.2661 \\
0.2772 \\
0.2782 \\
0.2785 \\
0.2787 \\
0.2788 \\
0.2790\end{array}$ \\
\hline $\begin{array}{c}\text { Source } \\
\text { distance } \\
2.0 \mathrm{~cm}\end{array}$ & $\begin{array}{l}0.1 \\
0.2 \\
0.3 \\
0.4 \\
0.6 \\
0.8 \text { to } 10.0\end{array}$ & $\begin{array}{l}0.9031 \\
0.9051 \\
0.9054 \\
0.9054 \\
0.9055 \\
0.9056\end{array}$ & $\begin{array}{l}0.7015 \\
0.7071 \\
0.7078 \\
0.7080 \\
0.7082 \\
0.7083\end{array}$ \\
\hline $\begin{array}{l}\text { Source } \\
\text { distance } \\
3.0 \mathrm{~cm}\end{array}$ & $\begin{aligned} & 0.1 \\
& 0.2 \\
& 0.3 \\
& 0.4 \text { to } 10.0\end{aligned}$ & $\begin{array}{l}0.9533 \\
0.9541 \\
0.9542 \\
0.9542\end{array}$ & $\begin{array}{l}0.8501 \\
0.8525 \\
0.8528 \\
0.8529\end{array}$ \\
\hline $\begin{array}{c}\text { Source } \\
\text { distance } \\
4.0 \mathrm{~cm}\end{array}$ & $\begin{aligned} & 0.1 \\
& 0.2 \\
& 0.3 \\
& 0.4 \text { to } 10.0\end{aligned}$ & $\begin{array}{l}0.9728 \\
0.9732 \\
0.9733 \\
0.9733\end{array}$ & $\begin{array}{l}0.9115 \\
0.9127 \\
0.9128 \\
0.9129\end{array}$ \\
\hline $\begin{array}{c}\text { Source } \\
\text { distance } \\
6.0 \mathrm{~cm}\end{array}$ & $\begin{array}{l}0.1 \\
0.2 \\
0.3 \text { to } 10.0\end{array}$ & $\begin{array}{l}0.9876 \\
0.9877 \\
0.9877\end{array}$ & $\begin{array}{l}0.9591 \\
0.9595 \\
0.9596\end{array}$ \\
\hline
\end{tabular}

TABLE IX

$A R E A 2.0 \mathrm{~cm}^{2}$, radius $0.79 \mathrm{~cm}$, thickness $0.4 \mathrm{~cm}$

\begin{tabular}{|c|c|c|c|}
\hline \multicolumn{2}{|c|}{$\begin{array}{l}\text { Energy } \\
(\mathrm{MeV})\end{array}$} & $J_{2} / J_{0}$ & $J_{4} / J_{0}$ \\
\hline Source & 0.1 & 0.7199 & 0.2688 \\
\hline distance & 0.2 & 0.7426 & 0.3139 \\
\hline $1.0 \mathrm{~cm}$ & 0.3 & 0.7465 & 0.3216 \\
\hline & 0.4 & 0.7476 & 0.3238 \\
\hline & 0.6 & 0.7485 & 0.3255 \\
\hline & 0.8 & 0.7488 & 0.3261 \\
\hline & 1.0 & 0.7490 & 0.3266 \\
\hline & 2.0 & 0.7494 & 0.3274 \\
\hline & 4.0 to 10.0 & 0.7496 & 0.3276 \\
\hline
\end{tabular}

TABLE IX (suite)

Source
distance
$2.0 \mathrm{~cm}$

Source distance $3.0 \mathrm{~cm}$

Source

distance

$4.0 \mathrm{~cm}$

4.0 to 10.0

0.9032

0.7018

0.7195

0.7225

0.7234

0.7240

0.7243

0.7245

$0.9112 \quad 0.7248$

$0.9113 \quad 0.7249$

$0.9533 \quad 0.8501$

$0.9556 \quad 0.8573$

$0.9560 \quad 0.8585$

$0.9561 \quad 0.8589$

$0.9562 \quad 0.8591$

$0.9562 \quad 0.8592$

$0.9563 \quad 0.8592$

$0.9563 \quad 0.8594$

$0.9563 \quad 0.8595$

0.1

0.9728

0.9115

0.2

0.9739

0.9150

0.3

0.9741

0.9742

0.9156

0.4

0.9742

0.9157

0.8

0.9742

0.9159

0.9159

1.0 to 10.0

0.9743

0.9160

Source

distance

0.1

0.9876

0.9591

0.2

0.9879

0.9603

$6.0 \mathrm{~cm}$

0.3 to 10.0

0.9880

0.9606

Source

distance

0.1

0.9929

0.9766

0.2

0.9931

0.9772

$8.0 \mathrm{~cm}$

0.3 to 10.0

0.9931

0.9773

\section{TABLE $\mathbf{X}$}

AREA $2.0 \mathrm{~cm}^{2}$, radius 0.79 , thickness $0.6 \mathrm{~cm}$

\begin{tabular}{|c|c|c|c|}
\hline \multicolumn{2}{|c|}{$\begin{array}{l}\text { Energy } \\
(\mathrm{MeV})\end{array}$} & $J_{2} / J_{0}$ & $J_{4} / J_{0}$ \\
\hline $\begin{array}{c}\text { Source } \\
\text { distance } \\
1.0 \mathrm{~cm}\end{array}$ & $\begin{array}{l}0.1 \\
0.2 \\
0.3 \\
0.4 \\
0.6 \\
0.8 \\
1.0 \\
2.0 \\
4.0 \\
6.0 \text { to } 10.0\end{array}$ & $\begin{array}{l}0.7187 \\
0.7524 \\
0.7602 \\
0.7626 \\
0.7644 \\
0.7651 \\
0.7656 \\
0.7665 \\
0.7667 \\
0.7667\end{array}$ & $\begin{array}{l}0.2659 \\
0.3359 \\
0.3524 \\
0.3575 \\
0.3612 \\
0.3628 \\
0.3638 \\
0.3656 \\
0.3663 \\
0.3664\end{array}$ \\
\hline $\begin{array}{c}\text { Source } \\
\text { distance } \\
2.0 \mathrm{~cm}\end{array}$ & $\begin{array}{l}0.1 \\
0.2 \\
0.3 \\
0.4 \\
0.6 \\
0.8 \\
1.0 \\
2.0 \\
4.0 \text { to } 10.0\end{array}$ & $\begin{array}{l}0.9026 \\
0.9121 \\
0.9142 \\
0.9148 \\
0.9153 \\
0.9155 \\
0.9156 \\
0.9159 \\
0.9159\end{array}$ & $\begin{array}{l}0.7002 \\
0.7274 \\
0.7335 \\
0.7353 \\
0.7367 \\
0.7373 \\
0.7376 \\
0.7383 \\
0.7385\end{array}$ \\
\hline
\end{tabular}


TABLE X (suite)

$\begin{array}{cccc}\text { Source } & 0.1 & 0.9530 & 0.8492 \\ \text { distance } & 0.2 & 0.9566 & 0.8605 \\ 3.0 \mathrm{~cm} & 0.3 & 0.9574 & 0.8630 \\ & 0.4 & 0.9577 & 0.8638 \\ & 0.6 & 0.9579 & 0.8643 \\ & 0.8 & 0.9579 & 0.8648 \\ & 1.0 & 0.9580 & 0.8650 \\ & 2.0 & 0.9580 & 0.8650 \\ \text { Source } & 4.0 \text { to } 10.0 & 0.9581 & 0.8651 \\ \text { distance } & 0.1 & 0.9727 & 0.9110 \\ 4.0 \mathrm{~cm} & 0.2 & 0.9744 & 0.9168 \\ & 0.3 & 0.9748 & 0.9178 \\ & 0.4 & 0.9749 & 0.9181 \\ & 0.6 & 0.9750 & 0.9184 \\ & 0.8 & 0.9750 & 0.9185 \\ & 1.0 & 0.9751 & 0.9186 \\ \text { Source } & 2.0 & 0.9751 & 0.9187 \\ \text { distance } & 0.0 \text { to } 10.0 & 0.9751 & 0.9188 \\ 6.0 \mathrm{~cm} & 0.1 & 0.9875 & 0.9589 \\ & 0.2 & 0.9881 & 0.9608 \\ & 0.3 & 0.9882 & 0.9612 \\ \text { Source } & 0.4 & 0.9883 & 0.9615 \\ \text { distance } & 0.6 \text { to } 10.0 & 0.9883 & 0.9616 \\ 8.0 \mathrm{~cm} & 0.1 & 0.9929 & 0.9766 \\ & 0.2 & 0.9931 & 0.9774 \\ & 0.3 & 0.9932 & 0.9776 \\ & 0.4 & 0.9932 & 0.9776 \\ \text { to } 10.0 & 0.9932 & 0.9777\end{array}$

TABLE XI

AREA $2.5 \mathrm{~cm}^{2}$, radius $0.89 \mathrm{~cm}$, thickness $0.35 \mathrm{~cm}$

\begin{tabular}{|c|c|c|c|c|}
\hline \multicolumn{3}{|c|}{$\begin{array}{l}\text { Energy } \\
(\mathrm{MeV})\end{array}$} & $J_{2} / J_{0}$ & $J_{4} / J_{0}$ \\
\hline $\begin{array}{c}\text { Source } \\
\text { distance } \\
1.0 \mathrm{~cm}\end{array}$ & 4.0 & $\begin{array}{l}0.1 \\
0.2 \\
0.3 \\
0.4 \\
0.6 \\
0.8 \\
1.0 \\
2.0 \\
\text { to } 10.0\end{array}$ & $\begin{array}{l}0.6766 \\
0.6963 \\
0.6993 \\
0.7001 \\
0.7008 \\
0.7010 \\
0.7012 \\
0.7015 \\
0.7016\end{array}$ & $\begin{array}{l}0.1907 \\
0.2244 \\
0.2293 \\
0.2307 \\
0.2317 \\
0.2321 \\
0.2324 \\
0.2329 \\
0.2330\end{array}$ \\
\hline $\begin{array}{c}\text { Source } \\
\text { distance } \\
2.0 \mathrm{~cm}\end{array}$ & 4.0 & $\begin{array}{l}0.1 \\
0.2 \\
0.3 \\
0.4 \\
0.6 \\
0.8 \\
1.0 \\
2.0 \\
\text { to } 10.0\end{array}$ & $\begin{array}{l}0.9425 \\
0.9448 \\
0.9452 \\
0.9453 \\
0.9454 \\
0.9454 \\
0.9454 \\
0.9454 \\
0.9455\end{array}$ & $\begin{array}{l}0.8170 \\
0.8241 \\
0.8252 \\
0.8255 \\
0.8257 \\
0.8258 \\
0.8259 \\
0.8260 \\
0.8261\end{array}$ \\
\hline $\begin{array}{c}\text { Source } \\
\text { distance } \\
3.0 \mathrm{~cm}\end{array}$ & 0.6 & $\begin{array}{l}0.1 \\
0.2 \\
0.3 \\
0.4 \\
\text { to } 10.0\end{array}$ & $\begin{array}{l}0.9780 \\
0.9786 \\
0.9787 \\
0.9788 \\
0.9788\end{array}$ & $\begin{array}{l}0.9281 \\
0.9301 \\
0.9304 \\
0.9305 \\
0.9306\end{array}$ \\
\hline $\begin{array}{c}\text { Source } \\
\text { distance } \\
8.0 \mathrm{~cm}\end{array}$ & $0.4 \mathrm{t}$ & $\begin{array}{l}0.1 \\
0.2 \\
0.3 \\
\text { to } 10.0\end{array}$ & $\begin{array}{l}0.9912 \\
0.9913 \\
0.9914 \\
0.9914\end{array}$ & $\begin{array}{l}0.9708 \\
0.9715 \\
0.9715 \\
0.9716\end{array}$ \\
\hline $\begin{array}{l}\text { Source } \\
\text { distance } \\
10.0 \mathrm{~cm}\end{array}$ & $0.4 \mathrm{t}$ & $\begin{array}{l}0.1 \\
0.2 \\
0.3 \\
\text { to } 10.0\end{array}$ & $\begin{array}{l}0.9943 \\
0.9944 \\
0.9944 \\
0.9944\end{array}$ & $\begin{array}{l}0.9812 \\
0.9815 \\
0.9815 \\
0.9816\end{array}$ \\
\hline
\end{tabular}

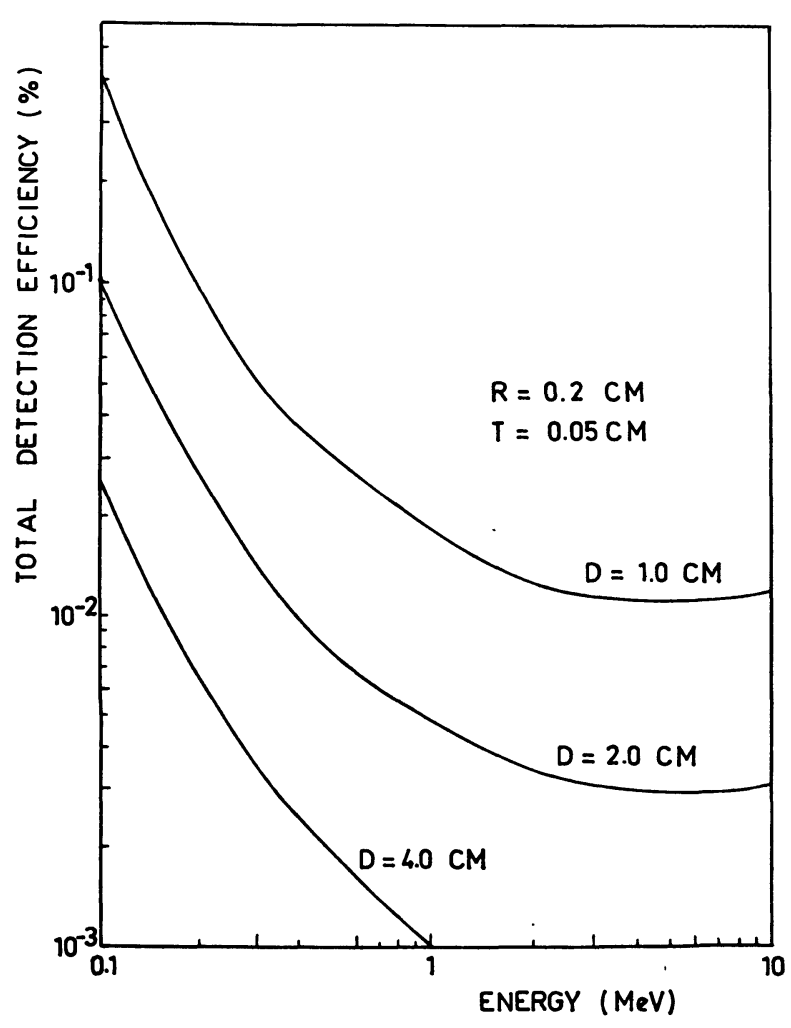

Fig. 2. - Total detection efficiency for CdTe detector with area $0.125 \mathrm{~cm}^{2}$ and thickness $0.05 \mathrm{~cm}$ Vs. gamma ray energies for different source to detector distances.

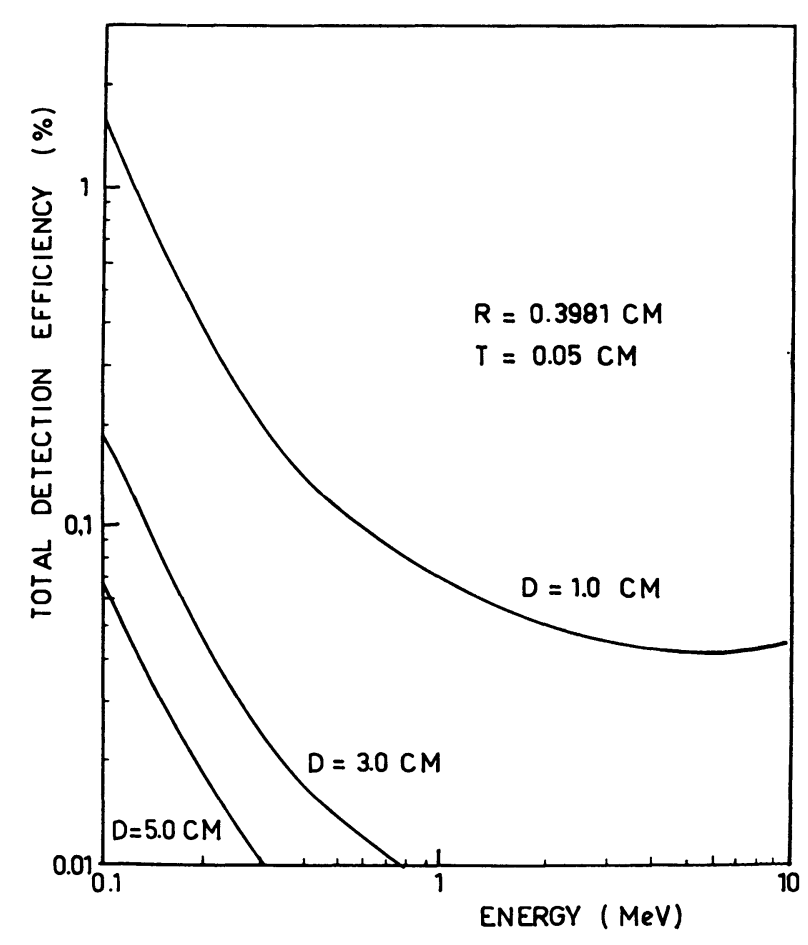

FIG. 3. - Total detection efficiency for CdTe detector with area $0.5 \mathrm{~cm}^{2}$ and thicknes $0.05 \mathrm{~cm}$ Vs gamma ray energies for different source to detector distances. 


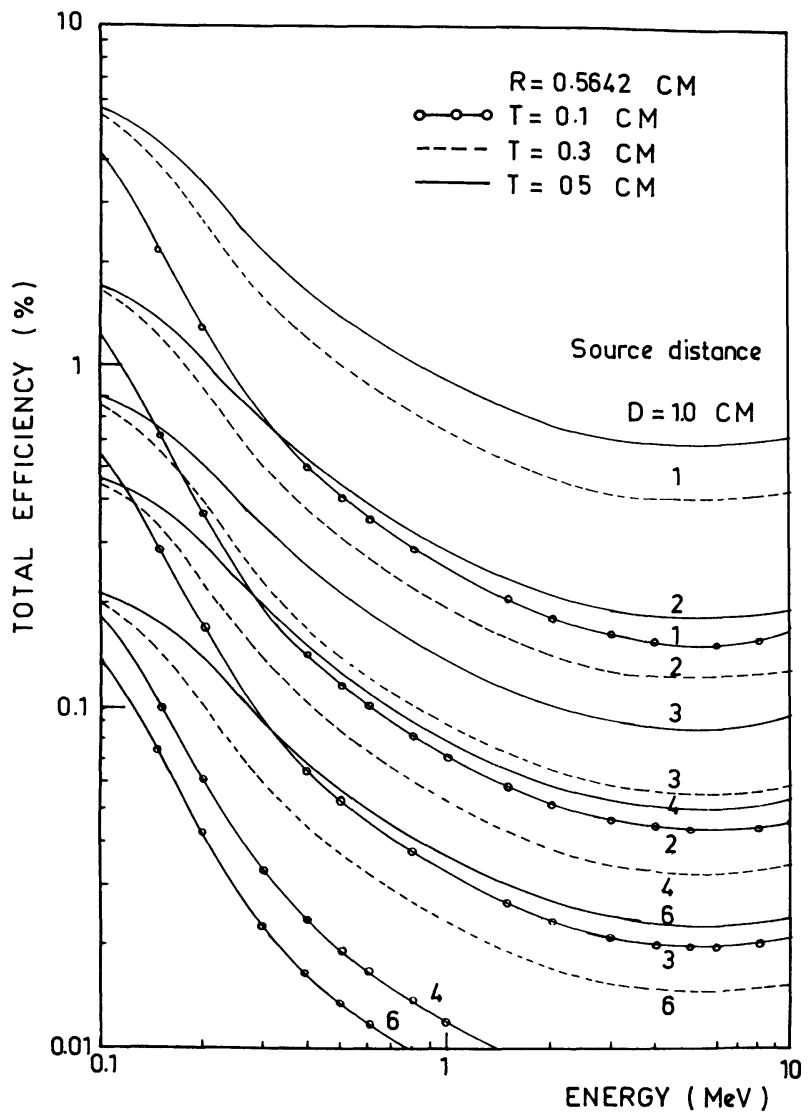

Fig. 4. - Total detection efficiency for CdTe detectors with area $1.0 \mathrm{~cm}^{2}$ and thickness $0.1,0.3$ and $0.5 \mathrm{~cm}$ Vs. gamma ray energies for different source to detector distances.

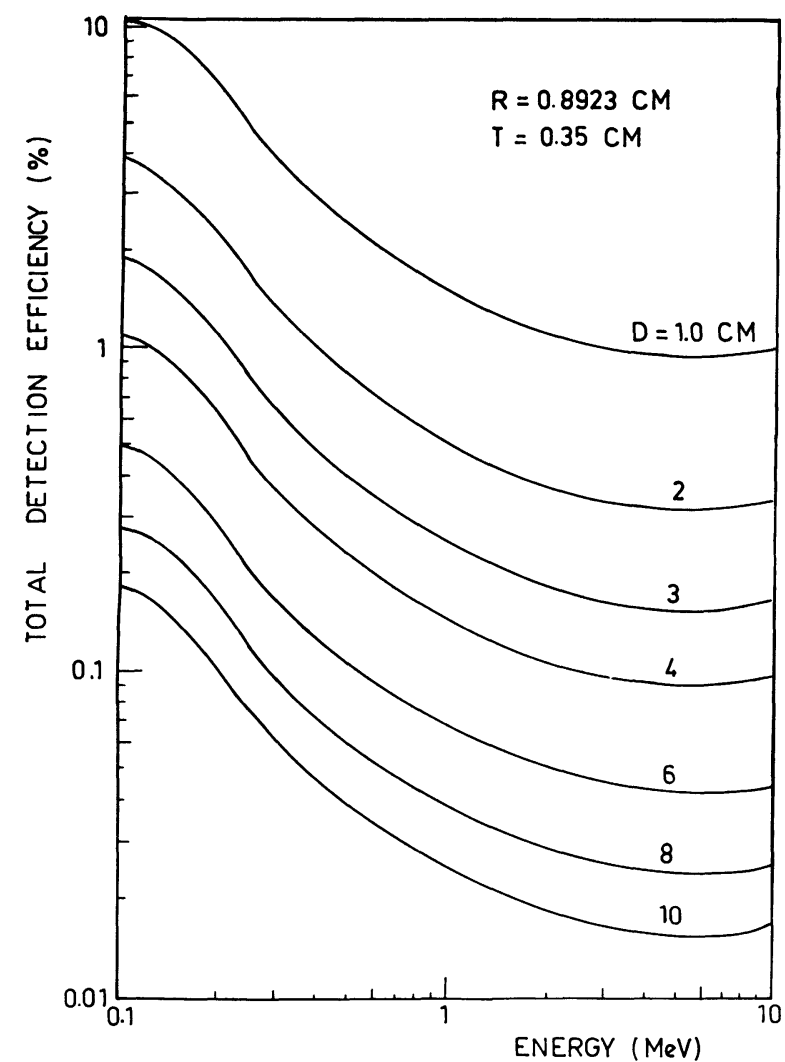

FIG. 5. - Total detection efficiency for CdTe detector with area $1.5 \mathrm{~cm}^{2}$ and thickness $0.1 \mathrm{~cm}$ Vs gamma ray energies for various source to detector distances.

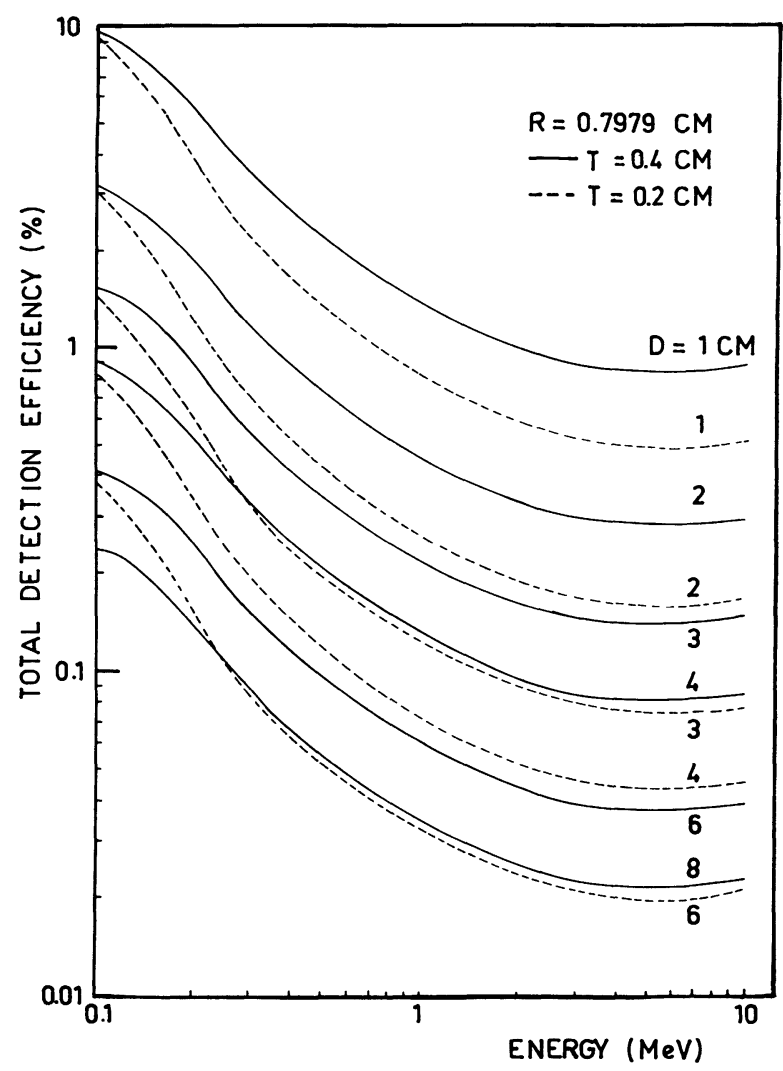

Fig. 6. - Total detection efficiency for CdTe detectors with area $2.0 \mathrm{~cm}^{2}$ and thickness 0.2 and $0.4 \mathrm{~cm}$ Vs gamma ray energies for various source to detector distances.

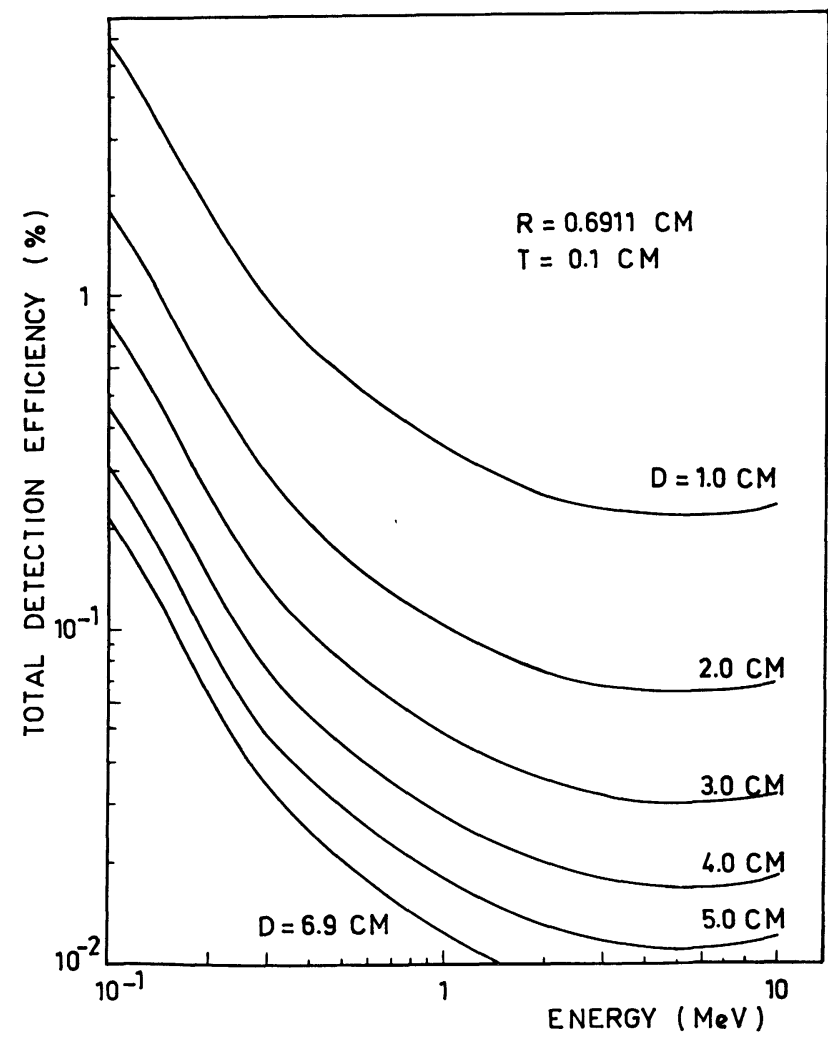

FIG. 7. - Total detection efficiency for CdTe detector with area $2.0 \mathrm{~cm}^{2}$ and thickness $0.6 \mathrm{~cm}$ Vs gamma ray energies for different source to detector distances. 


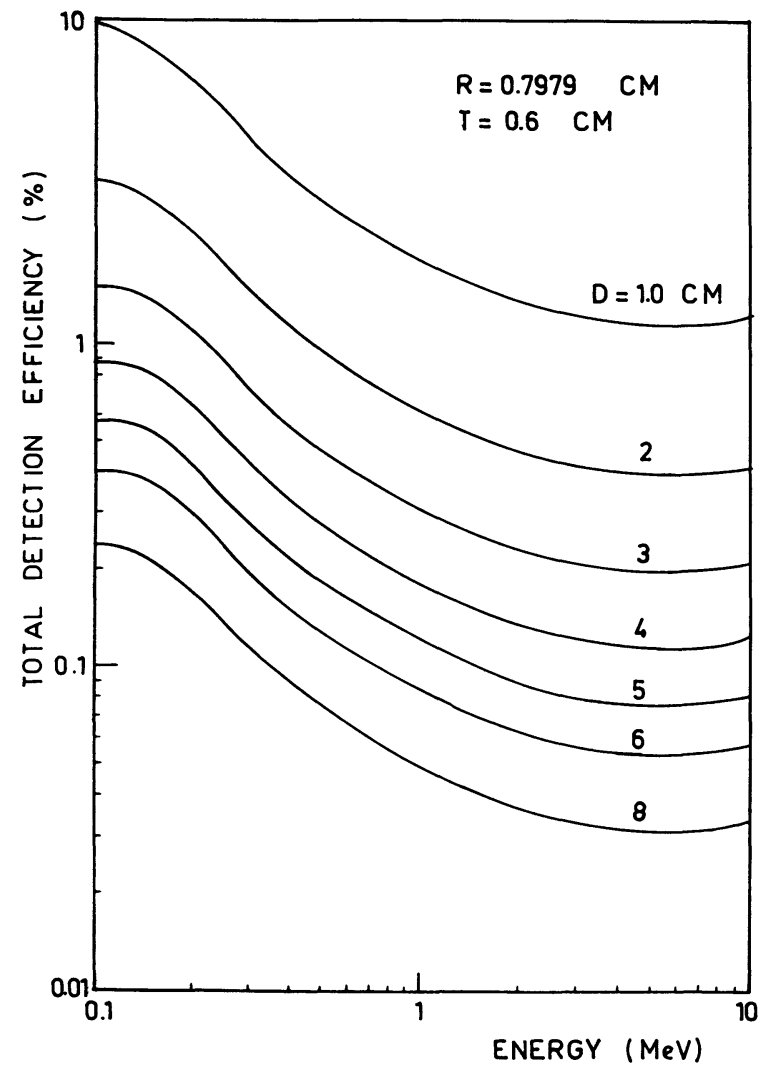

FIG. 8. - Total detection efficiency for CdTe detector with area $2.5 \mathrm{~cm}^{2}$ and thickness $0.35 \mathrm{~cm}$ Vs gamma ray energies for different source to detector distances.

3. Discussion. - Owing to the lack of experimental results on CdTe detectors it was not possible to develop relatively simple analytic formula for calculating $\varepsilon(E)$ 's and $J_{i} / J_{0}$. Therefore the data on these detectors has been provided using the method developed for $\mathrm{Ge}(\mathrm{Li})$ detectors for calculating $\varepsilon(E)$ 's and $Q_{i}$ 's. Firstly, we calculated the $\varepsilon(E)$ and $Q_{i}$ for $\mathrm{Ge}(\mathrm{Li})$ detectors and compared them with the values of Black and Gruhle [8], after obtaining satisfactory agreement between our values and Black et $a l$. we proceeded to CdTe calculations. The calculations presented in this paper are based on the assumption that all the pulses produced by the interaction between a gamma ray of a given energy and the crystal are detected and included in the analysis. Sometimes only photopeak efficiency is required in the calculations. One can obtain the photopeak efficiency as follows :

Photopeak efficiency $=$

$=$ Absolute detection efficiency $\times$ Photofraction .

It is hard to obtain photopeak fraction theoretically because counts arise in the full energy peak both due to photoelectric effect and compton effect where the compton scattered photon is eventually absorbed in the crystal. The value of the photo fraction can be calculated using a Monte Carlo method. In fact, it would be rather good if one would measure photo fractions experimentally using calibrated radioactive sources. It would be appropriate to add that the effect of the possible error due to finite dimensions of source and dead layer before the depleted region should also be investigated. As the inclusion of these effects make the calculations cumbersone therefore, we have not taken them into account. Moreover, they do not affect the result very much. The values of $\mu(E)$ used in this paper are theoretical and may be in small error. Nevertheless, our calculations are correct enough to provide sufficient data on the efficiency and $Q_{i}$ values within the limits of the approximations made in the text.

The authors are thankful to Professor M.Z. R. Khan and Dr. M. L. Sehgal for their interest in this work. We would also like to thank the computer center programmers of the A. M. U. Aligarh for their help in programming.

\section{References}

[1] Canali, C., Martini, M., Ottaviani, G., Alberigi QuaRANTA, A. and ZAMIO, K. R., Nucl. Instrum. Meth. 96 (1971) 561 .

[2] Bell, R. O. and Wald, F. W., Procd. Int. Symp. CdTe (Centre de Recherches Nucléaires, Strasbourg, France) (1971).

[3] MILler, G. L., IEEE Trans. Nucl. Sci. NS-19 (1972) 251.

[4] CAMP, D. C. and van LeHN, Nucl. Instrum. Meth. 46(1967) 213.
[5] Rose, M. E., Phys. Rev. 91 (1953) 610.

[6] Lawson, J. S. and Fraunfelder, H., Phys. Rev. 91 (1953) 649.

[7] Storm, E., Gilbert, D. and Israel, H., Nucl. Data Tables A 7 (1970) 565.

[8] Black, J. L. and GruHLE, W., Nucl. Instrum. Meth. 46 (1967) 213. 